\title{
Influence of Lawn Exhibitions and Brand Outlets on Consumers Buying Behavior
}

\author{
Ulita Umbreen ${ }^{1}$ \\ Muhammad Zaki Rashidi ${ }^{2}$
}

\begin{abstract}
For past 6 years the textile industry is leveraging tremendously by raising the bar in terms of product development, brand building, placement, style and presentation to increase accessibility to luxury. In this context, this research is undertaken to analyze the influence of lawn exhibitions and brand outlets towards consumers buying behavior and preferences. This research further investigates the consumers' responses to the current trends of pricing strategy of the lawn prints. It is descriptive in nature and a survey questionnaire is used which was consisted of 315 female consumers living in Karachi. The research focused on lawn exhibitions and brand outlets, shopping malls, beauty salons by taking the views of female consumers. The questionnaire was developed to find out about women living in Karachi whether they are influenced by the trend of branded lawn suits, promotions, exhibitions/brand outlets, styles and quality. The study's conceptual framework included six independent variables which were considered key dimensions of consumer buying behavior; one moderating variable-consumers demographics-plays a vital role in buying decisions. The research also found a strong positive relationship between lawn exhibition, brand outlets and consumer buying behavior. Although the consumers buying patterns, choices, purchasing power and accessibility may differ among female consumers, all like to wear lawn prints for various reasons.
\end{abstract}

Keywords: Brand outlets, buying behavior, consumer preferences, lawn prints exhibitions

\section{Introduction}

This research aims to highlight the lawn fashion suits trends (i.e. lawn brands arrivals, designers' and celebrity lawn print's exhibitions and giant brand outlets) to find out the factors that influence consumers' lawn prints buying behavior. The study focuses on the lawn prints' consumers preferences; the influence of brand's marketing promotions and launches of new arrival on consumer's buying decisions. During past 6 years many changes have taken place in buying behavior of consumers with reference to purchasing lawn suits across different segments of society. Keeping the consumers' demographics in view, this research assesses consumers' preferences and buying behaviors for the lawn prints which are also influenced by the culture, living styles and weather of the region/city and its existing market trends. The demand for new lawn prints has added value in textile industry and has become a trend with aggressive marketing promotions.

According to research studies done on the theme (Bushman 2007; Khalid 2011) most of the purchasing is made by the female consumers which continues to amplify. In view of Bushman (2007) several researches have shown that women are now making the majority of purchases in every field and industry some of which are not traditionally considered as 'female friendly'. On the other hand, women are more targeted by the marketers due to their impulsive buying habit, due to the fact that they are more involved in shopping (Bushman 2007). In Pakistan, lawn prints are always the most favorite fabric of women. Initially, lawn fabric used to be a preferred

${ }_{1}^{1}$ Ulita Umbreen is visitng faculty at Indus University, Karachi, uulita@yahoo.com

${ }^{2}$ Muhammad Zaki Rashidi is Assistant Professor at SZABIST, Karachi, zaki@ szabist.edu.pk

\begin{tabular}{llll|l}
\hline JISR-MSSE & Volume 10 & Number 2 & July 2012 & 45
\end{tabular}


choice due to the hot weather of the country gradually it has become fashion and most trendy fabric culminating into a lawn craze (Imam 2011) that continues to amplify. However, women being lascivious with lawn prints did not eventuate overnight; it developed gradually over a decade. Today, the arrival of summer is celebrated with a bonfire of lawn exhibitions and seasons of new arrivals by several brands in Pakistan and women desperately wait to visit these exhibitions and outlets for new arrivals of lawn prints (Khalid 2011).

Pakistani fashion industry is now encouraging a culture of consumerism with glamorous presentations of apparels (Andrew 2011). Earlier, with few well-known brands and designers only high profiled consumers were the target market of branded lawn suits but now the expensive big designers' lawn prints are available for the masses (Rezvi 2012). Depending on the satisfaction of consumers with a product, consumers continue using and recommending the product. (Bhattacherjee 2001 cited in Susana et al. 2008). The emerging fashion of lawn prints in Pakistani textile industry has influenced the consumers' choices for apparel. In a similar context, Hartley and Montgomery (2009) explained that the consumer is valuable; significantly contributing in driving the change in culture which strategically fits fashion with the lifestyle. Women are highly influenced by lawn fashion consisted of designers, lavish prints, exhibitions, brand outlets, catalogues and advertisements that have directly influenced consumers' choices and decisions. Increase in female workforce has changed their buying behavior but, in general, women as consumers of all profiles and demographics love to spend on apparel, accessories and branded clothing, particularly on lawn prints (Rajgopal 2010). Consumers' choices of wearing branded lawn suits and fashionable apparel is becoming a very important and essential aspect of the culture of Karachi.

The profusion of lawn exhibitions is the sign of summer time; women of Pakistan belonging to any profession and status desperately wait and keep their eyes on billboards to see the exhibition venue of their favorite lawn brands and even look for new entrants as well (Andrew 2011). The lawn prints exhibition model was first pioneered by apparel designer duo Sana and Safina who have been in the industry for last five years working with the textile mills, and with their outstanding designs and success the race began (Rezvi 2012). The main contenders of lawn exhibitions are the designers who have invaded the city with lawn suits carnivals and their success made giant old brands to refurbish their products and services so they could continue to maintain their position in the market efficiently (Andrew 2011). The blend of several factors has influenced the female consumers buying behavior which includes brands' tags, designers' innovation and creations, celebrities' endorsement, banners and billboards of lawn brands promoting designer lawn exhibitions, especially endorsed by models, TV and international film actresses (Imran 2011).

Lawn exhibitions are becoming a popular trend for distribution channel among the lawn producers in Pakistan fashion industry. These fashion designers are using a push model through various BTL (below the line) marketing activities in major cities of Pakistan. According to Mona (2013) BTL marketing tools effectively generate a personal and direct approach of marketing activities. Today, several firms are practicing non-media communications for promotions; and their activities may have less outreach but are progressing in small and large firms effectively (Zameer 2007; cited in Mona 2013). This study is intended to explore the influence of these exhibitions and brand outlets towards female consumers buying behavior. This study further differentiates the aggressive marketing of lawn industry in the wake of switching from functional to fashion industry.

\begin{tabular}{l|llll}
\hline 46 & July 2012 & Volume 10 & Number 2 & JISR-MSSE
\end{tabular}




\subsection{Research Problem}

This research aims to investigate the buying behavior of consumers which are influenced by several factors, including consumers' perceived quality, price, loyalty, luxurious product and services and social status and brand loyalty associated with the purchase of branded lawn suits. The study also evaluates as to what extent these lawn exhibitions, brand outlets, launch of new lawn prints, giant brands' discounts and sales offers are able to appeal the female consumers. Furthermore, it determines the relationship of the brand's image, promotions, accessibility, price, celebrity endorsements with the demographics of female consumers and consumers' buying patterns of lawn prints.

\subsection{Research Questions}

- What are the different buying patterns of female consumers related to purchase of lawn in Karachi?

- Is there any relationship of brands image, promotions, accessibility, price, celebrity endorsements with the demographics of female consumers of lawn prints?

- Do social status, brand loyalty, outlets, exhibitions, new arrivals and sale offers influence the buying behavior of female consumers towards buying branded lawn suits?

- Does the fashion-trend in lawn prints have positively influence brand image, premium quality, uniqueness, style, product development, placement and promotions?

- Does income level moderate the buying behavior of female consumers towards buying branded lawn suits?

- Do different attributes impact upon female consumers' preferences towards buying lawn prints?

\section{Literature Review}

Pakistani fashion industry is now encouraging a culture of merchandising with glamorous presentations. A research on "Consumer Culture and Purchase Intentions towards Fashion Apparel" (Rajgopal 2010) discovered about fashion that it has covered many aspects of consumers' daily life which may include clothes, households, jewelry, textile, and make over. Lawn industry has emerged as a fashion lawn industry, as giant brands and designers kept the separate stock of lawn pieces in their ateliers; initially creating a need by awareness about mixing and matching which later led to creating a preferred market (Imam 2011).

The vision brought by Pakistani designers to the textile industry has been taken seriously by manufacturers and mill owners who are investing and impacting to push the most "viable prêt" available in Pakistan (Imam 2011). Satisfaction as described by Susana (2008) is formed by the gap between perceived performance by the consumers and product's expectation with this description. The "expectation confirmation theory" suggests that if the perceived performance meets one's expectations, confirmation is formed (Oliver 1980 cited in Susana et al 2008). In his research Taylor (1958) cited in Susana et al. (2008) defined culture as "everything that a person learns in the environment and society which can be considered as a perfect blend of moral values, knowledge, beliefs, custom, art, law and individual capabilities". Culture is one of the most important factors which determine an individual behavior with respect to his/her society. Solomon and Schopler (1982) studied consumers' behviour and the extent to which they are concerned about their appearance, apparel, styles and their personality impressions. They

\begin{tabular}{llll|l}
\hline JISR-MSSE & Volume 10 & Number 2 & July 2012 & 47
\end{tabular}


concluded that the apparel understandings and measurements showed a persuasive and consistent correlation with scores on public self-consciousness (Kapoor \& Kulshrestha 2008). Though very limited literature on the effects of weather on consumers buying behavior has been considered by the marketers and scholars but according to the Steele (1951) weather affects the buying behavior of consumers. It was further highlighted by Parker and Tavassoli (2000) that weather of a particular region impacts the mood and spending. Parsons (2001) describes that weather shapes or influences the life style of people which mainly includes food, dress and other daily necessary items.

Jobber (2001) classified the influences on the consumers' buying behavior into three types:

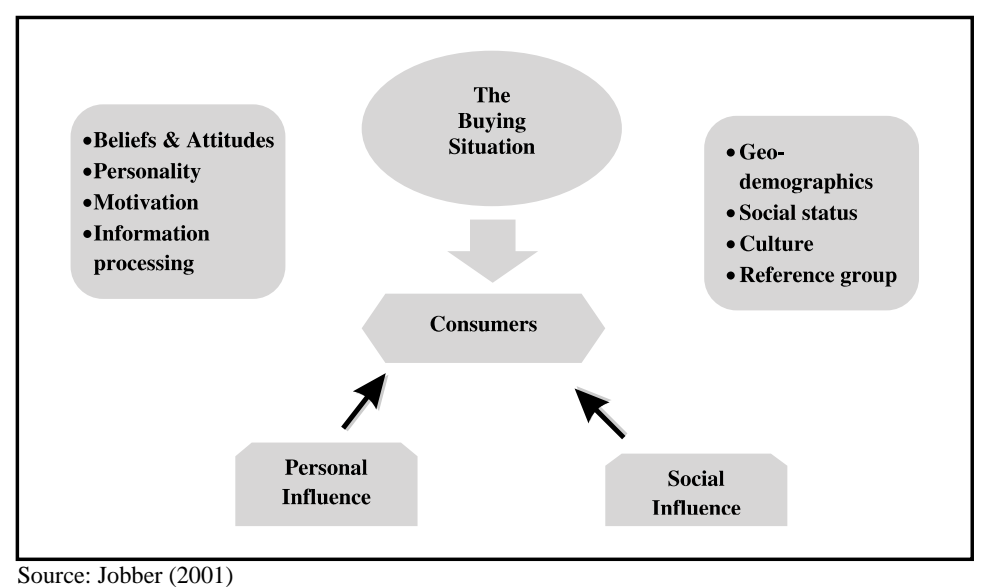

Figure 1: Influences on Consumer Buying Behavior

As stated by Jobber (2001) that while analyzing purchase of apparel, the consumers consider several factors based on their experiences, including prices and quality. They actually go through a problem solving phase in which the consumers do evaluations, they also get influenced by promotions, advertisements, brands and reference group before making a final buying decisions. Consumer behaviour for buying products and services, refers to his/her needs, wants, desires, learning, and other motives which are highly influenced by social factors. Social factors consist of an individual's living standards and styles, including family, friends, social class and reference group. As stated by Sinha (2012) that a consumer can be identified through the reference to the extent which he/she takes on the basis of several beliefs, attitudes, values behavior of different group members. Female consumer buying decision for the lawn suits are influenced by their social role and status (Sinha 2012). Thus, female consumers choose the lawn prints based on their status, standards, likeliness, comforts, personality and individuality, which may vary depending on a set of factors, mainly on status (Fischer \& Arnold 1994).

Consumer buying behavior and preference changes with the passage of time. As family life cycle consists of different phases i.e. from childhood to teenage, being single to married etc; this helps marketers focus appropriately on the target market (Jobber 2001). The occupation of an individual has a significant impact on his/her buying behavior and decision. The economic situation plays a vital role in consumer buying behavior because consumers make buying decision based on their purchasing power. Bonfire of lawn prints has exclusively focused on each consumer according to their age range, status, and occupations (Qamar 2012).

\begin{tabular}{l|llll}
\hline 48 & July 2012 & Volume 10 & Number 2 & JISR-MSSE
\end{tabular}


Female consumers' choices of wearing branded lawn suits, unbranded suits and fashionable apparel is becoming a very important and essential aspect of the culture of Karachi. The targeted segment is getting influenced prominently from media, aggressive promotion activities and the concept of branded and expensive product for the mass in lesser prices comparing to their original high price products (Jen 1990 cited in Susana et al, 2008). Younger consumers and female consumers occupy stronger product and services involvement and their purchase preferences and final decisions (O' Cass, 2001 cited in Kapoor and Kulshrestha 2008, p. 3). Every summer women from Lahore to Karachi are greatly focused to shopping malls, brand outlets and departmental stores to get the preview of the endless variety of lawn available (Imam 2011). As the research conducted by Clavo and Marrero (2009 cited in Rajgopal 2010) concluded the distinctive characteristics of fashion like media and celebrity endorsement, designer brands have strong association with the emotional depiction that plays a vital role in the consumers buying behavior. Several big designers entered the lawn industry and this trend is growing immensely and a huge number of fashion designers entered into this business by lending their label to textile manufacturers: Sana Safinaz, Nomi Ansari, Nadia Husain, HSY, Sara Shahid, Shamaeel, Maria B, Rizwan Beyg, Sobia Nazir and Sonya Battla, are already established names in the fashion industry (Imam 2011). The leading producers and manufacturers in the textile industry have also started booming since last few years, as they are domestically focused towards lawn prints because lawn prints became the most sought after fabric in Pakistan (Anon 2012).

With a focus on domestic markets, the sellers and manufacturers of lawn are using four types of retailing channels which are further elaborated below:

Lawn Prints Exhibition is most successful channel to directly reach the target market initiated by the designer brands under the concept of designers' prints available to the mass market which have been adopted by almost all the designers and large textile brands to be a part of the race and capture the market as much as possible (Rezvi 2012). The Lawn Exhibition channel consists of implementation of aggressive advertisements, promotions through social, electronic and print media, celebrity and brand ambassador endorsements, fashion show events, traditional themes, exhibitions conducting on highly valued posh areas and glamorous launch of lawn prints (Taha 2012).

Brand Outlets is another retailing channel which is the most stable and appropriate model for selling the product where lawn prints are available throughout the year with unlimited ranges of fabric and through launches of several seasons and occasions the giant brand get the benefit by reaching out to the target market most efficiently (Muzaffar 2012).

Leading Stores/Malls is another way to sell the lawn prints as due to increasing lawn craze among the women various designers went to retailing through leading apparel stores famous for the women fabrics in a way to get the maximum benefits from the consumers so after exhibition several designers have used retailing through providing the prints pieces in leading stores of the city located in famous shopping malls and centers (Anon 2012).

Online/ E-Shopping is an extensive social media and electronic media driven channel. Retailers have started taking online orders through their websites within and outside the country, even using Facebook and Twitter to get their target audiences (Taha 2012). Gul Ahmed and few other designers have also started online ordering system to enjoy the lawn fabric sale profits (Rezvi 2012). Various other retailers are available on different websites: Facebook and Twitter where customer, after viewing the lawn prints options available, can order their desired one (Muzaffar 2012). The designers and mega mill owners are now using all these four retailing channels to optimize the outreach and promote their products.

\begin{tabular}{llll|l}
\hline JISR-MSSE & Volume 10 & Number 2 & July 2012 & 49
\end{tabular}




\section{Research Methodology}

\subsection{Research Design}

This is a quantitative (descriptive method) research about finding the consumer buying preferences and behavior towards buying lawn prints for which a survey is conducted to collect primary data from female consumers of Karachi.

\subsection{Population and Sampling}

Total estimated population of Karachi is over 21 million and the female population ratio is above 10 million out of which, for this research, the estimated population of female consumers of branded lawn suits is considered around 1 million (SEC A, SEC B and SEC B+).

In order to gather the effective data to study the influence of exhibitions and brand outlets towards consumers buying behavior the data was gathered by using convenience sampling due to accessibility. The data is collected from different shopping centers and malls located in Gulistan-e-Johar, Gulshan, PECHS and Clifton. The main shopping malls and centers were Millennium Shopping Mall (Dalmiya), Dolmen Mall \& Rabi Center (Tariq Road) Gul Ahmed Outlet at KDA Market, Gulf Shopping Market, Zamzama Street and Al-karam Studio near 2 swords circle. The collected data details are given below:

Table 1: Statistics

\begin{tabular}{|l|l|l|l|l|}
\hline S.No & Data Collected & $\begin{array}{l}\text { Total \# of } \\
\text { Respondents }\end{array}$ & $\begin{array}{l}\text { Complete } \\
\text { Questionnaires }\end{array}$ & $\begin{array}{l}\text { Incomplete } \\
\text { Questionnaires }\end{array}$ \\
\hline 1 & Lawn Exhibitions & 170 & $108(64 \%)$ & $62(36 \%)$ \\
\hline 2 & Other sources & 220 & $207(94 \%)$ & $24(6 \%)$ \\
\hline & Total & 390 & $315(81 \%)$ & $76(19 \%)$ \\
\hline
\end{tabular}

\subsection{Data Collection Procedure}

Total 390 questionnaires were distributed but 360 out of 390 were returned. Only 315 out of 360 were acceptable. As the target respondents were the female consumers so to get the ideal data the focus was on lawn exhibitions and new arrivals of lawn prints those areas where mostly ladies were conveniently available.

\subsection{Pilot Testing of the Questionnaire}

The research questionnaire was self-administered as no previous questionnaire was available so for content and face validity a pilot testing was conducted with 10 female consumers in Karachi and these were not included in final research. Respondents were asked to fill up the questionnaire and then the questionnaires were checked to confirm for understanding the questions and the required time for completing the questionnaire by each respondent was around 10 minutes.

\subsection{Research Variables}

As stated by James and Brett (1984) that moderator variable influences the strength or direction of the relations among the predictor or independent variables and criterion or dependent variables

\begin{tabular}{l|llll}
\hline 50 & July 2012 & Volume 10 & Number 2 & JISR-MSSE
\end{tabular} 
in both qualitative (illuminating races, gender, class and race) and quantitative (expressing the level of delights and rewards) forms. In the same context, this study identifies the consumers' demography as a moderating variable where the age, gender, personal profile and class status have their influence in buying lawn prints from exhibitions, outlets or shopping malls, which finally affects the buying behavior of female consumers.

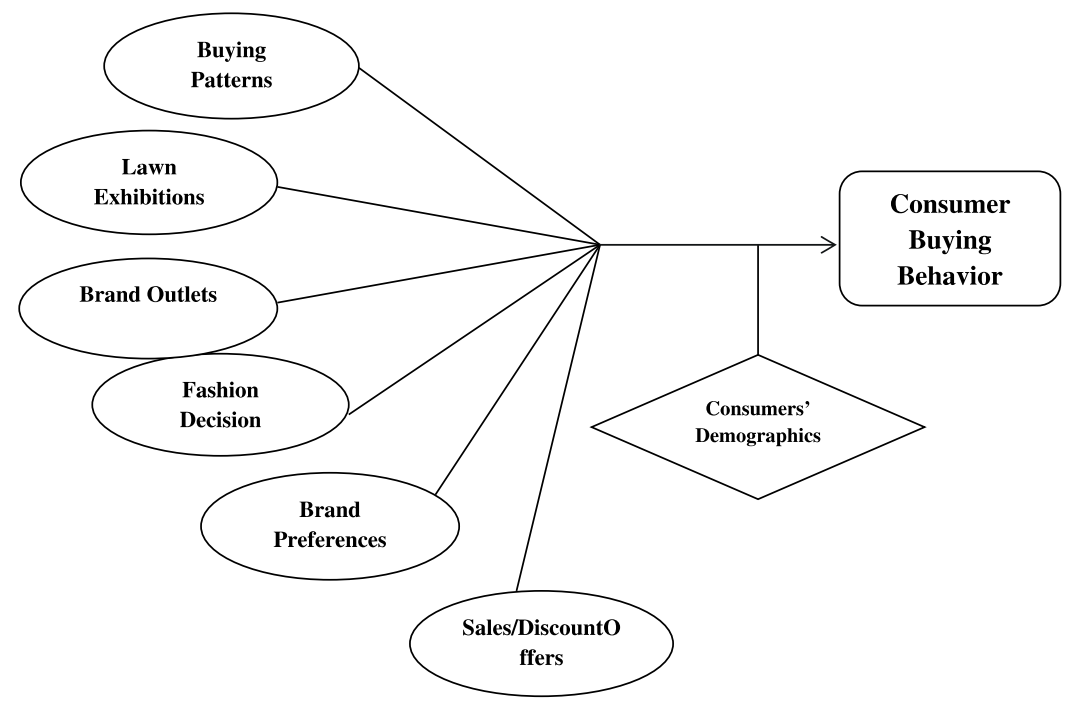

Figure 2: Consumer Buying Behavior

\section{Data Analysis and Findings}

The questionnaires which were returned were entered into SPSS version 17 after proper coding. The entered coded data was crosschecked and corrected wherever it was required. Descriptive and frequency analyses were done for verification and graphs and frequency were used to analyze the pattern of the data. Hypotheses were examined by correlation and regression tests. The reliability of questionnaire was tested by the Cronbach's alpha coefficient computation to test the internal consistency of the constructs. The items which were near to .60 alpha values were retained for this study. The face and content validity of the questionnaire is assured by the feedback of the respondents and experts.

\subsection{Demographic Profile}

The data for this research was collected from female consumers in Karachi, available in lawn exhibitions, shopping malls, beauty parlors and universities. Frequency analysis shows that out of 315 respondents $37 \%$ were house wives, $25 \%$ students and $38 \%$ were employed. The age represents $29 \%$ female consumers were between the age group 16-24, $29 \%$ between 25-32, $24 \%$ between 33-40 and 11\% between 41-50. Income represents that based on gross income per month $12 \%$ respondents' income was between $0-50,000,20 \%$ were between $50,000-75,000$, $26 \%$ respondents' income was between 75,000-100,000, $26 \%$ respondents' income between $100,000-150,000$ and $20 \%$ were above 150,000 . 
The age analysis shows that a majority with $29.2 \%$ was between $25-32$ years old and other with $28.6 \%$ was between 16-24 years older were luminously the most interested consumers buyers for the lawn prints among all age groups. Similarly out of 315 respondents most were the house wife and employed with a minor differences from $37.1 \%$ to $37.8 \%$. As the study is about buying behavior toward lawn suits and findings showed that most of them belonged to the income between $75000-100,000$ which is $26.3 \%$ of the total and 100,000-150,000 (25.4) and this study has also highlighted that majority of respondents were graduate with $34.3 \%$ then intermediate contributing total $24.1 \%$.

\subsection{Cross-Tabulation Analysis}

The cross-tabulation analysis of the study reveals that demographic factors are more influential towards buying behavior of lawn prints. The research finding about the female consumers status and age limits show that female consumer's age range with respect to their status who are influenced to buy lawn prints. Out of total 315 respondents 117 were housewife, 119 were employed and 79 were students. The test represents that out of 315 female consumers, 83 belonged to: $75,000-100,000,80$ belonged to: 100,000-150,000, 63 belonged to: Above 150,000, 51 to $50,000-75,000$ and 38 belonged to $0-50,000$. This shows that young female consumers with high income level are more influenced towards buying lawn prints. This combination of income and education shows that mostly buying lawn prints involves an educated segment with high incomes as among the respondents mostly are graduates and post graduates.

\subsection{Descriptive Analysis of Research Variables}

Through descriptive analysis the study found that with high mean value of 3.74 and 3.57 respondents from exhibitions are highly influenced by lawn exhibitions and brand outlets towards buying lawn prints and 3.78 the highest mean value shows that the respondents are more interested in sales/ discounts offers and these variables with high mean value also affecting consumer buying behavior with mean value 3.4. Fashion and brand preference mean value 2.9 shows comparably like other variables consumers are less influenced and buying patterns having the mean value 2.4 shows that it may vary with respect to time, place and price so all these three on neutral response. The mean value of lawn exhibitions, brand outlets and fashion shows that consumers are influenced by lawn exhibitions and brand outlets towards buying lawn prints and as they are highly involved in brand preferences which do change their buying behavior and on average fairly they are influenced by lawn prints sales /discounts offers.

The study has highlighted the female consumer's opinion about the attributes of fashion and brand preferences which are involved towards their lawn prints buying decisions. Respondents were asked to rank these attributes, 1 being the most preferred and 5 being the least preferred. Graph represents their priorities and preferences. Each attribute being influential toward lawn prints purchasing calculated on the basis of average (Figure 3).

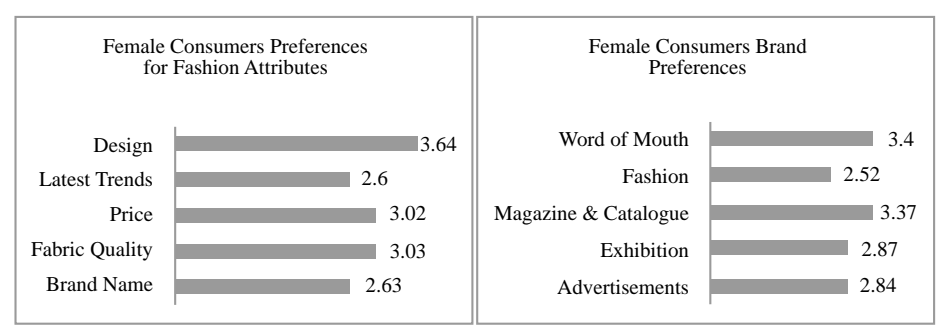

Figure 3: Female Consumer Preference for Brand and Fashion Attributes

\begin{tabular}{l|llll}
52 & July 2012 & Volume 10 & Number 2 & JISR-MSSE
\end{tabular}


According to the research out of 315 respondents almost all of them visits all the places where lawn prints of different brands are available but how frequently they buy from each place it varies. This descriptive analysis highlights the experiences, preferences, opinion and influences of 315 respondents towards buying lawn prints. This study found that with mean values 3.021 and 2.83 which mildly skewed towards lawn prints sales/ a discount offers preferences as compare to buying branded lawn prints.

The study further investigates the consumers' experiences of buying lawn prints, like after visiting lawn exhibitions/ brand outlets and experiencing branded lawn suits the mean values shows consumers neutral responses between 3 to 3.17 which might be because of various reason like dissatisfactions or neutral responses towards fabric quality, price, availability designs and many more but they are satisfied when asked about lawn brand's advertisements and promotions with mean value of 3.73 shows positive attitudes. The consumer's buying preferences from the lawn exhibitions and brand outlets were studied and found that with high mean value of 3.43 and 3.2 of premium fabric quality and lawn brands promotions are the main reason that consumers prefer exhibitions and brand outlets for buying lawn prints and other mean values between 2.91 to 3.05 shows neutral responses that they might be dissatisfied with the designer's style, brand name and other add-on of the lawn prints. Similarly based on consumers' experiences the mean values 3.23 and 3.48 shows that with lenient difference consumers have high influence of brand outlets than lawn exhibitions which might be because of outlets are easily approachable throughout the year.

The descriptive analysis of variables shows that over all with mild differences in the mean values of 3.14 and 3.18 shows that lawn exhibitions and brand out lets are influencing consumers and affecting consumer buying behavior while considering other constructs having values between 2.4 to shows 3.06 show that due to several reasons consumers have neutral responses towards fashion, brand preferences and sales/discount offers which might be due to high branded prices, fabric quality, limited few sales/discounts offers. Most of the values of standard deviations are close to 1.47 showing the values are scattered more from the mean.

\subsection{Correlation Analysis}

To study the correlation among 7 variables of the research, Pearson Coefficient correlation was used. The study found that buying patterns are not correlated with lawn exhibition, brand outlets, fashion, brand preferences, sales/discount offers and consumer buying behavior because the values of significance are greater than .05 . The study is able to conclude that the correlation between Lawn exhibitions and Brand outlet are positively correlated with .911 which is extremely strong relationship i.e., change in exhibitions will influence consumer buying decision, and brand outlets as well. Hence, lawn prints exhibition is significantly correlated with brand outlet, but it is not significantly correlated with buying patterns, fashion and brand preferences due to the greater $\mathrm{p}$. values. 
Table 2: Correlation Analysis

\begin{tabular}{|lccccccc|}
\hline & $\begin{array}{l}\text { Buying } \\
\text { Decision }\end{array}$ & $\begin{array}{c}\text { Lawn } \\
\text { Exhibitions }\end{array}$ & $\begin{array}{c}\text { Brand } \\
\text { Outlets }\end{array}$ & Fashion & $\begin{array}{c}\text { Brand } \\
\text { Preferences }\end{array}$ & $\begin{array}{r}\text { Sales/ } \\
\text { Discounts }\end{array}$ & $\begin{array}{c}\text { Consumer } \\
\text { Buying }\end{array}$ \\
& & & & & & & \\
Offers & Behavior \\
\hline Buying Decision & 1 & & & & & & \\
Lawn Exhibition & .051 & 1 & & & & & \\
Brand Outlets & .011 & $.911^{* *}$ & 1 & & & & \\
Fashion & -.023 & -.017 & .003 & 1 & & & \\
Brand Preferences & -.026 & -.031 & -.042 & -.072 & 1 & & \\
Sales/ Discounts & -.086 & $.183^{* *}$ & $.411^{* *}$ & .048 & -.033 & 1 & \\
Offers & & & & & & & \\
Consumer Buying & -.023 & $.154^{* *}$ & $.175^{* *}$ & $-.123^{*}$ & -.081 & .040 & 1 \\
Behavior & & & & & & & \\
\hline
\end{tabular}

Two more significant positive correlations are between lawn exhibition and sales or discount offers on lawn suits which is 0.183 and between brand outlets and sales or discounts offers is 0.411 , showing that if influence of lawn exhibitions and brand outlets will increase or decrease then sales or discounts offers will also increase or decrease for both branded and un-branded products towards consumer buying decisions. Consumer buying behavior has also a significant stronger relationship with lawn exhibitions and brand outlets which are 0.154 and 0.175 which means that if there is an increase/decrease in influence of lawn exhibitions and brand outlets then that will also affect by increasing/decreasing the influence of consumer buying behavior towards buying lawn prints.

The research also reveals the correlation between brand outlet, fashion, brand preferences, sales/discounts offers and consumers behavior and found that there is no significant correlation between the buying patterns, fashion and brand preferences. The study further determined the correlation between the fashion and brand preferences, sales/discount offers and consumer buying behavior and found that there is a negative correlation between fashion and consumer buying behavior which is -.123 which shows they are inversely correlated if fashion influence will increase then consumer buying behavior will decrease; it can be the impact of high prices of the lawn prints or limited purchasing power. The study found no significant relationship between the fashion and brand preference and sales/discount offers. Other correlations were also found insignificant.

\subsection{Regression Analysis}

Value of adjusted R2 is .038 which is very low than the benchmark value of 0.6 stipulating only

Table 3: ANOVA

\begin{tabular}{|lll|l|l|l|l|l|}
\hline RESPONDENTS & \multicolumn{2}{|c|}{ Model } & $\begin{array}{l}\text { Sum of } \\
\text { Squares }\end{array}$ & \multicolumn{1}{c|}{ df } & $\begin{array}{c}\text { Mean } \\
\text { Square }\end{array}$ & \multicolumn{1}{|c|}{ F } & Sig. \\
\hline Exhibition's & 1 & Regression & 4.084 & 6 & .681 & 1.807 & $.105^{\mathrm{a}}$ \\
Respondent & & Residual & 38.041 & 101 & .377 & & \\
& Total & 42.125 & 107 & & & \\
\hline Other than Exhibition's 1 & Regression & 5.257 & 6 & .876 & 2.240 & $.041^{\mathrm{b}}$ \\
Respondents & Residual & 78.224 & 200 & .391 & & \\
& Total & 83.481 & 206 & & & \\
\hline
\end{tabular}

\begin{tabular}{l|llll}
\hline 54 & July 2012 & Volume 10 & Number 2 & JISR-MSSE
\end{tabular}


$3.8 \%$ variation in consumer buying behavior is explained by the independent variables. However, significant value 0.007 of ANOVA is lower than the tabulated value of 0.05 which shows independent variables explained the variation in dependent variable. Therefore, there is no evidence to accept null hypothesis and reject it at alpha 5\%. Also the tabulated value of consumer buying behavior and fashion is significant i.e. less than 0.05 showing their beta values to be significant while for remaining variables beta values are insignificant.

It may be concluded that sale offers, buying preferences, fashion, buying decision, lawn exhibition and brand outlets do explain variation in consumer buying behaviors. The regression analysis was also performed on the basis of split file (exhibition's respondents and non-exhibition) to check variation in the results, where value of adjusted $\mathrm{R} 2$ is .043 and .035 stipulating in exhibition respondents more variation is explained $4.3 \%$ compare with non-exhibition $3.5 \%$ by the independent variables. However, in ANOVA non exhibition respondents has significant value 0.041 than the tabulated value of 0.05 which shows independent variables explained the variation in dependent variable.

\section{Conclusion}

In recent years' a drastic change is observed in Pakistan textile industry, which is now more focused towards lawn prints and prêt which have been strongly associated with the fashion industry. It affected the society in terms of being fashion focused, exhibition trends, lawn fashion shows, more designer and branded looks, and tags; which means that consumers have seen and experienced a substantial growth. In the context of analyzing the influence of lawn exhibitions and outlets, this study was focused towards the female consumers' demographics, i.e., increase in women work force made consumers more fastidious and demanding in the market due to which lawn producers and designers effectively adapted the strategies that has appealed the female consumers more. They have created a new culture and trend that influenced female buyers.

This study highlighted the demographic factors of female consumers that have a great impact on their buying behavior specifically for the lawn prints which include female consumer's status, age, income and education and accordingly the buying behavior and preferences vary. The study findings revealed that due to unlimited availability of designer brands, mega lawn brands and other producers, female consumers are not particular for a specific brand name or tag, they look for options available and then take decision and considering the consumers buying behavior theory and literature of past research papers, the findings of this study also conclude that exhibitions and brand outlets have tremendously changed the buying behavior of consumers through implementation of aggressive advertisements, promotions through social, electronic and print media, celebrity and brand ambassador endorsements, fashion show events, traditional themes but at the end the purchasing power makes consumers limited in terms of spending. Another aspect which appeals and attracts consumers effectively is the brand outlet, as the research findings highlight that consumers prefer this channel due to the availability of fabric throughout the year, with new arrivals on different occasions and events in the country, as other fabric varieties are available like cloths for men and children, prêt, bed sheets, duvets, hand bags etc. But the most important aspect is that consumers like their sales and discount offers which is for the limited time period.

Research findings also highlight the role of leading shopping malls and stores which make consumers impulsive buying decisions. Retailing has also been started online through social media and websites, which remains on the mind of consumers and they do check the promotions and updates online, and it confirms the importance of lawn exhibitions, brand outlets, sales/discount

\begin{tabular}{llll|l}
\hline JISR-MSSE & Volume 10 & Number 2 & July 2012 & 55
\end{tabular}


offers and aggressive promotions in influencing and changing the female consumers buying behavior. The study also reveals the importance of female as a consumer of lawn prints in Pakistan. The lawn prints have emerged as a fashion lawn prints and continue to boom but this research showed that there are several reasons that female consumers are still not fashion conscious because still most of this segment looks for fabric quality instead of only designs and prints. Although young consumers are more design, colour and fashion conscious but are limited due to their affordability which emphasized on the buying power and social status of the consumers; hence income level of female consumers moderates the final buying decisions. Female consumers have almost the same opinion for both exhibitions and brand outlets even buying the lawn prints most of the respondents were not particular about the place or location.

The study found that unlimited variety of lawn brands available, female consumers looks for more options which are eliminating a trend being loyal to a specific brand. This research helps in identifying several variables that are influencing consumer's behavior. Consumers became more apparent and look for alternatives due to their own reasons which may include fabric quality, price, latest trends, brand tags, ads, fashion, exhibitions, brand outlets, discount offers and many other factors. Conclusively, lawn exhibitions and brand outlets have their influence on female consumers towards changing their buying behavior and preferences, although they have created a huge and stiff market in Pakistan that continues to grow and raising the bar of Pakistan's textile and fashion industries, to represent them internationally.

\section{References}

Andrew, M 2011, “The great lawn crossover”, Aurora, 2 June 2011, available from: http://Aurora The great lawn crossover.mht

Anon 2012, “Textile wars: lawn fest”, The Express Tribune, 18 February 2012, available from: http://tribune.com.pk/story/338369/textile-wars-lawn-fest

Bushman, M 2007, "Business strategy: marketing to women”, Yahoo Contributor Network, 8 August 2012, available from: http://voices.yahoo.com/business-strategy-marketing-women365214.html

Imam, Z 2011, “Lawn: fashion's democrat”, Aurora, 4 March 2011, available from: http://auroramagazine.blogspot.com/search?q=lawn+suits

Imran, A 2011, “Attracting the ladies who lawn”, Aurora, 2 June 2011, available from: http:\\Aurora The great lawn crossover.mht

Jackson, SL 2009, Research Methods and Statistics: A Critical Thinking Approach, $3^{\text {rd }}$ edition Wadsworth, Belmont, CA.

James, LR \& Brett, JM 1984, "Mediators, moderators, and tests for mediation", Journal of Applied Psychology, vol. 69, no. 2, pp. 307-321.

Jobber, D 2001, Principles \& Practice of Marketing, Andy Goss, United Kingdom.

\begin{tabular}{l|llll}
\hline 56 & July 2012 & Volume 10 & Number 2 & JISR-MSSE
\end{tabular}


Kapoor, A \& Kulshrestha, C 2008, "The effect of perception on India urban female consumer buying behavior", Monash Business Review, vol.4, no.1, pp. 1-12, available from: http://corecentre.co.in/Database/Docs/DocFiles/urban_female.pdf

Kavishree, R \& Nandhini, G 2007, "Fashion retail in apparel sector", available from: http://www.fibre2fashion.com/industry-article/37/3656/fashion-retail-in-apparel-sector

Khalid, S 2011, “10 Things I hate about designer's lawn”, The Express Tribune, 10 April 2011, available from: http://tribune.com.pk/story/144360/10-things-i-hate-about-designer-lawns

Mona, C 2013, "Perception of retailers towards below the line initiatives of mall management in NCR", International Journal of Scientific Research, vol. 2, no. 4, April 2013, ISSN: $2277-$ 8179, available from: http://theglobaljournals.com/ijsr/file.php?val=Nzky

Muzaffar, EN 2012, "Mirror mirror come on, it's just lawn”, Women's Magazine, 28 February 2012, available from: http://e.thenews.com.pk/newsmag/mag/detail_article.asp?magId=1\&id=1354

Parker, PM \& Tavassoli, NT 2000, "Homeostasis and consumer behavior across cultures", International Journal of Research in Marketing, vol. 17, issue 1, 31 March 2000, pp. 33-53.

Parsons, AG 2001, "The association between daily weather and daily shopping patterns", Australasian Marketing Journal, vol. 9, no. 2, pp. 78-84.

Rezvi, M 2012, “Tribune take: lawn tsunami to sweep Pakistan”, The Express Tribune, 8 February 2012, available from: http://tribune.com.pk/story/333481/tribune-take-lawn-tsunami-to-sweeppakistan

Rajgopal, V 2010, “Consumer culture and purchase intentions towards fashion apparel”, Working Paper/MKT, 2010, EGADE Business School, Monterrey Institute of Technology and Higher Education, Mexico.

Steele, AT 1951, "Weather's effect on the sales of a department store", Journal of Marketing, vol. 15 , no. 4, April 1951, pp. 436-443.

Susana, A, Madalena, P, Joao, F\& Vilma, P 2008, “Consumer buying behavior in fashion retailing: empirical evidences”, MPRA Paper, vol.6, no. 11, pp. 407-413.

Taha, H 2012, "Lawn: back to the racks", The Express Tribune, 19 February 2012, available from: http\ltribune.com.pk/story/332973/lawn-back-to-the-racks/?print=true

Taha, H 2012, “Lawn 2012: will be epidemic be as widespread as last year's", The Express Tribune, 19 February 2012, available from: http://hanitaha.wordpress.com/2012/02/19/lawn2012-will-the-epidemic-be-as-widespread-as-last-years 


\section{Appendix}

Table 4: Female Consumer's Demographic Matrix

\begin{tabular}{|c|c|c|c|c|c|c|c|}
\hline S.No & $\begin{array}{c}\text { Demographic } \\
\text { Of } \\
\text { Respondents }\end{array}$ & Frequency & $\begin{array}{c}\text { Percent } \\
\text { age }\end{array}$ & S.No & $\begin{array}{l}\text { Demographic } \\
\text { Of } \\
\text { Respondents }\end{array}$ & Frequency & $\begin{array}{c}\text { Percent } \\
\text { age }\end{array}$ \\
\hline \multirow[t]{6}{*}{1} & STATUS & & & 3 & INCOME & & \\
\hline & House Wife & 117 & $37.1 \%$ & & $0-50,000$ & 38 & $12.1 \%$ \\
\hline & Student & 79 & $25.1 \%$ & & $\begin{array}{l}50,000- \\
75,000\end{array}$ & 51 & $16.2 \%$ \\
\hline & Employed & 119 & $37.8 \%$ & & $\begin{array}{l}75,000- \\
100,000\end{array}$ & 83 & $26.3 \%$ \\
\hline & & & & & $\begin{array}{l}100,000- \\
150,000\end{array}$ & 80 & $25.4 \%$ \\
\hline & & & & & $\begin{array}{l}\text { Above } \\
150,000\end{array}$ & 63 & $20.0 \%$ \\
\hline \multirow[t]{6}{*}{2} & AGE & & & 4 & $\begin{array}{l}\text { EDUCATIO } \\
\mathbf{N}\end{array}$ & & \\
\hline & $16-24$ & 90 & $28.6 \%$ & & $\begin{array}{l}\text { Matric/ } \\
\text { Level }\end{array}$ & 57 & $18.1 \%$ \\
\hline & $25-32$ & 92 & $29.2 \%$ & & $\begin{array}{l}\text { Intermediate/ } \\
\text { A Level }\end{array}$ & 76 & $24.1 \%$ \\
\hline & $33-40$ & 76 & $24.1 \%$ & & $\begin{array}{l}\text { Graduate } \\
\text { Degree }\end{array}$ & 108 & $34.3 \%$ \\
\hline & $41-50$ & 36 & $11.4 \%$ & & $\begin{array}{l}\text { Master's } \\
\text { Degree }\end{array}$ & 74 & $23.5 \%$ \\
\hline & Above 50 & 21 & $6.7 \%$ & & & & \\
\hline
\end{tabular}

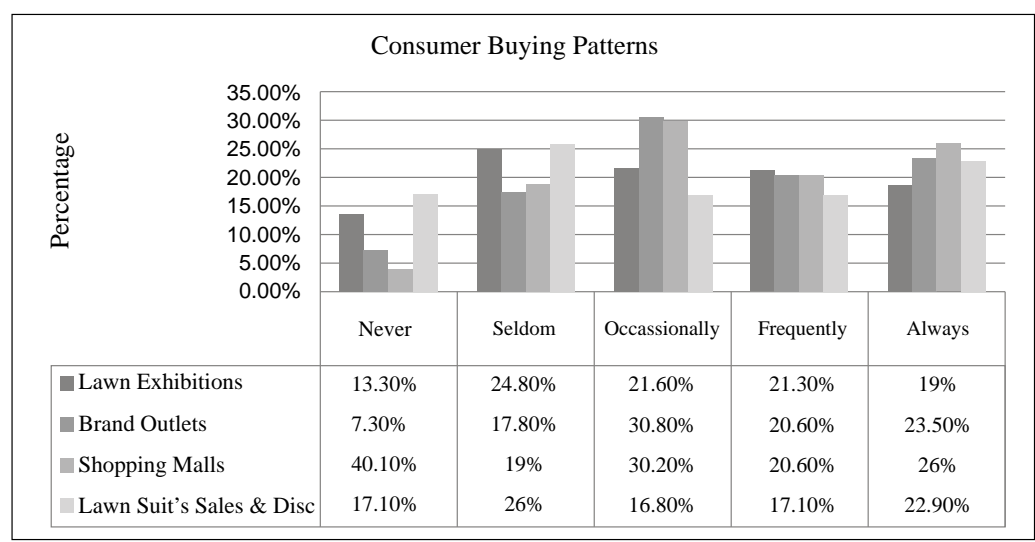

Figure 4: Female Consumers Buying Patterns towards Lawn Prints 
Table 5 : Descriptive Analysis

\begin{tabular}{|l|l|l|l|l|}
\hline Statements & Minimum & Maximum & Mean & $\begin{array}{c}\text { Std. } \\
\text { Deviation }\end{array}$ \\
\hline Branded Exhibition/ Brand Outlets & 1 & 5 & 2.83 & 1.326 \\
\hline Sales/Discount Offers & 1 & 5 & 3.01 & 1.474 \\
\hline Visiting Lawn Exhibitions & 1 & 5 & 3.17 & 1.396 \\
\hline Visiting Brand Outlets & 1 & 5 & 3.12 & 1.265 \\
\hline Experience of Branded Lawn Prints & 1 & 5 & 3.01 & 1.245 \\
\hline Brand Promotion activities/Ads & 1 & 5 & 3.73 & 1.150 \\
\hline Brand Name & 1 & 5 & 3.05 & 1.358 \\
\hline Public Image Driven & 1 & 5 & 2.91 & 1.410 \\
\hline Premium Quality & 1 & 5 & 3.43 & 1.379 \\
\hline Designer's Style & 1 & 5 & 2.98 & 1.390 \\
\hline Uniqueness/ Accessories & 1 & 5 & 3.04 & 1.402 \\
\hline Promotions & 1 & 5 & 3.20 & 1.425 \\
\hline Exhibition Experience & 1 & 5 & 3.23 & 1.244 \\
\hline Brand Outlets Experience & 1 & 5 & 3.48 & 1.193 \\
\hline
\end{tabular}

Table 6 : Descriptive Analysis

\begin{tabular}{|l|l|l|}
\hline Variables & Mean & $\begin{array}{l}\text { Std. } \\
\text { Deviation }\end{array}$ \\
\hline Buying Patterns & 2.4317 & 1.05770 \\
\hline Lawn Exhibition & 3.1440 & .51001 \\
\hline Brand Outlets & 3.1824 & .56773 \\
\hline Fashion & 2.9867 & .15541 \\
\hline Brand Preferences & 3.0000 & .09169 \\
\hline Sales/Discounts Offers & 3.0063 & 1.47375 \\
\hline Consumers Buying Behavior & 3.2278 & .64706 \\
\hline
\end{tabular}

Table 7 : Exhibition's Respondents

\begin{tabular}{|c|c|c|c|c|c|c|c|}
\hline & $\begin{array}{l}\text { Buying } \\
\text { Decision }\end{array}$ & $\begin{array}{c}\text { Lawn } \\
\text { Exhibitions }\end{array}$ & $\begin{array}{l}\text { Brand } \\
\text { Outlets }\end{array}$ & Fashion & $\begin{array}{c}\text { Brand } \\
\text { Preferences }\end{array}$ & $\begin{array}{l}\text { Sales/ } \\
\text { Discounts } \\
\text { Offers } \\
\end{array}$ & $\begin{array}{c}\text { Consumer } \\
\text { Buying } \\
\text { Behavior }\end{array}$ \\
\hline Buying Decisions & 1 & & & & & & \\
\hline Lawn Exhibitions & .042 & 1 & & & & & \\
\hline Brand Outlet & -.044 & $.776 * *$ & 1 & & & & \\
\hline Fashion & -.047 & .021 & .111 & 1 & & & \\
\hline $\begin{array}{l}\text { Brand } \\
\text { Preferences }\end{array}$ & -.021 & .060 & .036 & .181 & 1 & & \\
\hline $\begin{array}{l}\text { Sales/Discounts } \\
\text { Offers }\end{array}$ & -.054 & -.021 & $.337 * *$ & $.216^{*}$ & .065 & 1 & \\
\hline $\begin{array}{l}\text { Consumer Buying } \\
\text { Behavior }\end{array}$ & -.055 & -.087 & .084 & -.110 & .056 & .109 & 1 \\
\hline
\end{tabular}

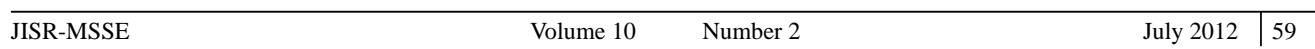


Table 8 :Other than Exhibition's Responents

\begin{tabular}{|c|c|c|c|c|c|c|c|}
\hline & $\begin{array}{c}\text { Buying } \\
\text { Decision }\end{array}$ & $\begin{array}{c}\text { Lawn } \\
\text { Exhibitions }\end{array}$ & $\begin{array}{l}\text { Brand } \\
\text { Outlets }\end{array}$ & Fashion & $\begin{array}{c}\text { Brand } \\
\text { Preferences }\end{array}$ & $\begin{array}{c}\text { Sales/ } \\
\text { Discounts } \\
\text { Offers }\end{array}$ & $\begin{array}{c}\text { Consumer } \\
\text { Buying } \\
\text { Behavior }\end{array}$ \\
\hline Buying Decisions & 1 & & & & & & \\
\hline Lawn Exhibitions & .059 & 1 & & & & & \\
\hline Brand Outlet & .019 & $.881 * *$ & $\mathbf{1}$ & & & & \\
\hline Fashion & -.002 & .006 & .013 & 1 & & & \\
\hline Brand & -.028 & .008 & .010 & $-.196 * *$ & 1 & & \\
\hline Preferences & & & & & & & \\
\hline $\begin{array}{l}\text { Sales/Discounts } \\
\text { Offers }\end{array}$ & -.128 & -.092 & $.163^{*}$ & -.061 & -.028 & 1 & \\
\hline $\begin{array}{l}\text { Consumer Buying } \\
\text { Behavior }\end{array}$ & -.011 & .078 & .017 & -.127 & -.104 & -.135 & 1 \\
\hline
\end{tabular}

**Correlation is significant at the 0.01 level (2-tailed)

* Correlation is significant at the 0.05 level (2-tailed). 